\title{
Association between workaholism and quality of life in stricto sensu graduate professors in nursing
}

\author{
Associação entre workaholism e qualidade de vida em docentes de pós-graduação stricto sensu em enfermagem \\ Asociación entre adicción al trabajo y calidad de vida en stricto sensu Profesores graduados en enfermería
}

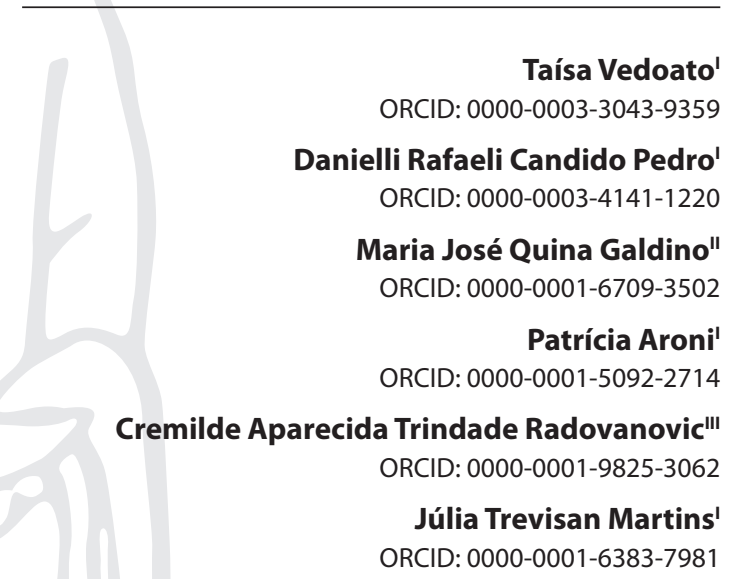

Maria do Carmo Fernandez Lourenço Haddad' ORCID: 0000-0001-7564-8563

'Universidade Estadual de Londrina. Londrina, Paraná, Brazil. "Universidade Estadual do Norte do Paraná. Bandeirantes, Paraná, Brazil.

"'Universidade Estadual de Maringá. Maringá, Paraná, Brazil.

How to cite this article: Vedoato T, Pedro DRC, Galdino MJQ, Aroni P, Radovanovic CAT, Martins JT, et al. Association between workaholism and quality of life in stricto sensu graduate professors in nursing. Rev Bras Enferm. 2021;74(2):e20190901. doi: http://doi.org/10.1590/0034-7167-2019-0901

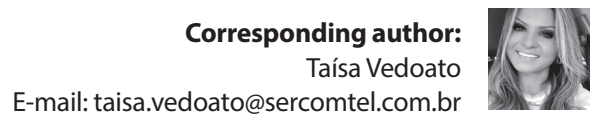

EDITOR IN CHIEF: Antonio José de Almeida Filho ASSOCIATE EDITOR: Hugo Fernandes

Submission: 07-06-2020 Approval: 09-24-2020

\begin{abstract}
Objectives: to investigate the association between workaholism and quality of life in stricto sensu graduate professors in Nursing. Methods: a cross-sectional study developed with a total of 333 professors working in the Graduate Programs of Brazilian public universities. Data collection took place in the second semester of 2018, using an electronic form containing a characterization questionnaire, the Dutch Work Addiction Scale and the World Health Organization Quality of Life Instrument-BREF. The data were analyzed by univariate and multiple logistic regression. Results: it was observed that $82.3 \%$ of the professors reported low general quality of life and $19.5 \%$, high level of excessive work and $20.1 \%$ of compulsive work. Professors who worked compulsively and excessively were less likely to have a high quality of life in the overall, physical, psychological, social relations and environment domains $(p<0.05)$. Conclusions: the high work demands that are characteristic of the stricto sensu professors' work process are directly associated with low quality of life.

Descriptors: Work; Quality of Life; Professors; Nursing; Universities.
\end{abstract}

\section{RESUMO}

Objetivos: investigar a associação entre o workaholism e a qualidade de vida em docentes de pós-graduação stricto sensu em Enfermagem. Métodos: estudo transversal desenvolvido com 333 docentes atuantes nos Programas de Pós-Graduação de universidades públicas brasileiras. A coleta de dados ocorreu no segundo semestre de 2018, por um formulário eletrônico contendo questionário de caracterização, a Dutch Work Addiction Scale e o World Health Organization Quality of Life Instrument-BREF. Os dados foram analisados por regressão logística univariada e múltipla. Resultados: observou-se que $82,3 \%$ dos docentes referiram baixa qualidade de vida geral, 19,5\% alto nível de trabalho excessivo e $20,1 \%$ mencionaram trabalho compulsivo. Os docentes que trabalhavam compulsiva e excessivamente apresentaram menores chances de alta qualidade de vida nos domínios overall, físico, psicológico, relações sociais e ambiente $(p<0,05)$. Conclusões: as altas demandas de trabalho características do processo de trabalho dos docentes stricto sensu estão associadas diretamente à baixa qualidade de vida.

Descritores: Trabalho; Qualidade de Vida; Docentes; Enfermagem; Universidades.

\section{RESUMEN}

Objetivos: investigar la asociación entre la adicción al trabajo y la calidad de vida de profesores de posgrado stricto sensu en Enfermería. Métodos: se trata de un estudio transversal, desarrollado con 333 profesores que trabajan en programas de posgrado de universidades públicas brasileñas. La recolección de datos tuvo lugar en el segundo semestre de 2018 mediante un formulario electrónico que contenía un cuestionario de caracterización, según la Escala Holandesa de Adicción al Trabajo y el Instrumento de Calidad de Vida de la Organización Mundial de la Salud (BREF). Los datos se analizaron con regresión logística univariante y múltiple. Resultados: se observó que el $82,3 \%$ de los docentes mencionó una baja calidad de vida en general, el 19,5\% un nivel alto de trabajo excesivo y el $20,1 \%$ comentó sobre trabajo compulsivo. Los profesores que trabajaban compulsivamente y en exceso presentaron menos posibilidades de tener calidad de vida alta en el ámbito general, físico, psicológico, de las relaciones sociales y del entorno $(p<0,05)$. Conclusiones: las grandes demandas laborales típicas del proceso de trabajo de los docentes stricto sensu están directamente relacionadas a una calidad de vida baja.

Descriptores: Trabajo; Calidad de Vida; Docentes; Enfermería; Universidades. 


\section{INTRODUCTION}

The search for efficiency and efficacy in universities contributed for professors to intensify their work routine. In particular, for graduate professors, the workload has increased considering the pressure for production of articles and the performance in different areas, such as teaching, commissions and supervising students ${ }^{(1-2)}$.

In this context, the professor work goes through a redefinition of the position in the social organization of work, in which subjectivity is built based on productivism, immediacy, resolute professionals and attentive to constant updates and unbridled competition $^{(1-2)}$.This scenario can contribute in a negative way, directly affecting the health of these professors. It is known that it is necessary for professors to spend a large amount of their time in graduate activities, which contributes to a compulsion for work and can be characterized as workaholic (addicted to work) ${ }^{(3)}$.

Workaholism is the excessive and uncontrollable need to work, comparing it to other addictions, such as alcoholism. There are five aspects of the addict's behavior at work: (I) working beyond what was asked; (II) self-esteem due to high productivity (III) abdication of personal needs and relationships; (IV) perfectionism; (V) constant mental concern with work ${ }^{(4)}$.

People addicted to work performs activities far beyond the proposals, not doing them because they are asked, but because they believe they are necessary and ends up getting in the way of their daily routines due to the high expectations on themselves, showing a lack of control over the hours dedicated to work and about the work itself ${ }^{(5)}$, which can harm their quality of life.

Quality of life (QL) involves how individuals perceive their position in life and it is a broad concept, which encompasses health in its physical, psychological spheres, independence level, social relationships, personal beliefs and the environment ${ }^{(6)}$.

In addition to the importance of knowing more deeply the quality of life phenomenon and its relationship with professor work, their working conditions as Graduate professors are added. Verifying the aspects involved in the work process of professors of Graduate Programs will allow the implementation of actions that favor their quality of life, as well as can produce benefits in the training of new professor-researchers nurse. Studies on educators' working conditions are included in national and international research agendas $s^{(7-8)}$.

\section{OBJECTIVES}

To investigate the association between workaholism and quality of life in stricto sensu graduate professors in Nursing.

\section{METHODS}

\section{Ethical aspects}

The study followed the resolution of the National Health Council $466 / 2012$, it was submitted and approved by the Research Ethics Committee (REC) from the State University of Londrina.

\section{Design, setting and period of study}

This is a cross-sectional study, with a quantitative approach, carried out with professors from the Graduate Nursing Programs
(PPGENF) recommended or recognized by CAPES, from Brazilian public universities.

The description of this study followed the Strengthening the Reporting of Observational Studies in Epidemiology (STROBE).

\section{Population or sample; inclusion and exclusion criteria}

The 917 professors of the referred PPGENF composed the study population, considering the following inclusion criteria: being a permanent professor, linked to a PPGENF in 2018. Exclusion criteria was professor in any kind of leave. Based on the population, the sample size was calculated adopting a prevalence of $50 \%$, as it results in the largest sample number, $95 \%$ confidence interval and maximum error of $5 \%$, which resulted in a minimum number of 270 professors. All 917 professors were invited to participate in the study by email, however, a total of 333 professors consented to participate in the study. Thus, this is an intentional sampling.

\section{Study protocol}

We used a total of three research instruments, composed of a questionnaire prepared by one of the authors with sociodemographic, lifestyle and health (gender, age, physical activity and use of antidepressants) and occupational variables (area of training, type of university, employment relationship and work regime, years of activity in higher education, number of links in graduate programs and number of master's/PhD students). This questionnaire was subjected to an intersubjective evaluation process by five doctored professors from graduate programs in the health area and not part of the study sample, who indicated their relevance and clarity in relation to the study object.

The Dutch Work Addiction Scale (DUWAS) was used to assess workaholism, the Brazilian version was validated, and its reliability was tested in Brazilian professionals, with Cronbach's alpha greater than 0.70 . The instrument contains a total of 10 items evaluated on a 4-point Likert scale, and measures both dimensions: Compulsive Work (CW) and Excessive Work (EW). Higher concomitant scores in each dimension indicate workaholism ${ }^{(9)}$.

Quality of life was assessed by the World Health Organization Quality of Life Assessment Instrument - Bref (WHOQOL-Bref), the Brazilian version was translated and validated, with Cronbach's alpha coefficient between 0.69 and 0.84 . The instrument contains a total of 26 items, with five-point Likert scale format responses, two general and the other ones were divided into four domains: physical (seven questions), psychological (six questions), social relations (three questions) and the environment (eight questions). The higher the score of the domains, the better the quality of life ${ }^{(10)}$.

The study instruments were inserted in an internet platform, built for this purpose by a team of programmers. The final version of the instrument was made available through a link sent to the professors' e-mail, which was obtained from the PPGENF pages. Access to the page was released only after acceptance to participate and sign the Informed Consent Form (ICF), and the instruments were available for completion from July to December 2018. 


\section{Analysis of results and statistics}

The data were analyzed in the Statistical Package for the Social Sciences (SPSS), version 22.0. The scores for the dimensions of workaholism and quality of life were divided into high and low, using the 75th percentile.

In descriptive statistics, frequencies and percentages were calculated. In inferential statistics, the relationship between the domains of quality of life and the dimensions of workaholism was assessed by univariate logistic regression and, later, by multiple logistic regression, the characterization variables were inserted in the model to adjust the relationship. $\mathrm{P}<0.05$ was considered statistically significant and the results were presented by odds ratio and $95 \%$ confidence interval.

\section{RESULTS}

Of the 333 professors, most were women (87.7\%), whose age ranged between 28 and 75 years old. Regarding lifestyle and health habits, $25.8 \%$ of participants self-reported being physically active and $14.4 \%$ reported using antidepressants. About working time, $45.6 \%$ of the professors had been teaching for more than 20 years and $66.7 \%$ had employment bond to federal universities. $45 \%$ of professors worked more than 11 hours a week in addition to the workload of their work contract, $70.3 \%$ were linked to only one PPGENF and $55.9 \%$ had 1 to 5 students being supervised at stricto sensu level (Table 1).

Table 1 - Sociodemographic and occupational characteristics of stricto sensu graduate professors in nursing ( $N=333)$, Brazil, 2018

\begin{tabular}{|c|c|c|}
\hline Variables & $\begin{array}{l}\text { Absolute } \\
\text { frequency }\end{array}$ & $\begin{array}{c}\text { Relative } \\
\text { frequency }\end{array}$ \\
\hline \multicolumn{3}{|l|}{ Gender } \\
\hline Male & 41 & 12.3 \\
\hline Female & 292 & 87.7 \\
\hline \multicolumn{3}{|l|}{ Age range } \\
\hline 28 to 50 & 147 & 44.1 \\
\hline 51 to 75 & 186 & 55.9 \\
\hline \multicolumn{3}{|c|}{ Physically active* } \\
\hline No & 247 & 74.2 \\
\hline Yes & 86 & 25.8 \\
\hline \multicolumn{3}{|l|}{ Depression } \\
\hline No & 285 & 85.6 \\
\hline Yes & 48 & 14.4 \\
\hline \multicolumn{3}{|c|}{ Type of university } \\
\hline State & 111 & 33.3 \\
\hline Federal & 222 & 66.7 \\
\hline \multicolumn{3}{|c|}{ Years of teaching in higher education } \\
\hline 1 to 20 & 181 & 54.4 \\
\hline 21 to 51 & 152 & 45.6 \\
\hline \multicolumn{3}{|c|}{ Senior professor } \\
\hline No & 309 & 92.8 \\
\hline Yes & 24 & 7.2 \\
\hline \multicolumn{3}{|c|}{ Weekly hours in addition to workload hours } \\
\hline 0 to 10 & 183 & 55.0 \\
\hline 11 to 58 & 150 & 45.0 \\
\hline \multicolumn{3}{|c|}{ Number of graduate programs linked } \\
\hline 1 & 234 & 70.3 \\
\hline 2 & 87 & 26.1 \\
\hline 3 & 12 & 3.6 \\
\hline \multicolumn{3}{|c|}{ Number of students being supervised } \\
\hline 1 to 5 & 186 & 55.9 \\
\hline 6 to 17 & 147 & 44.1 \\
\hline
\end{tabular}

Table 2 -Description of the domains of quality of life and workaholism of stricto sensu graduate professors in nursing ( $N=333)$, Brazil, 2018

\begin{tabular}{|c|c|c|}
\hline Variables & Frequency & $\%$ \\
\hline \multicolumn{3}{|c|}{ Overall quality of life } \\
\hline Low & 274 & 82.3 \\
\hline High & 59 & 17.7 \\
\hline \multicolumn{3}{|c|}{ Quality of life -Physical Domain } \\
\hline Low & 153 & 45.9 \\
\hline High & 180 & 54.1 \\
\hline \multicolumn{3}{|c|}{ Quality of life -Psychological domain } \\
\hline Low & 130 & 39.0 \\
\hline High & 203 & 61.0 \\
\hline \multicolumn{3}{|c|}{ Quality of life-Social relationships domain } \\
\hline Low & 167 & 50.2 \\
\hline High & 166 & 49.8 \\
\hline \multicolumn{3}{|c|}{ Quality of life -Environment domain } \\
\hline Low & 188 & 56.5 \\
\hline High & 145 & 43.5 \\
\hline \multicolumn{3}{|c|}{ Compulsive work } \\
\hline Low & 266 & 79.9 \\
\hline High & 67 & 20.1 \\
\hline \multicolumn{3}{|c|}{ Excessive work } \\
\hline Low & 268 & 80.5 \\
\hline High & 65 & 19.5 \\
\hline \multicolumn{3}{|c|}{ Workaholism } \\
\hline No & 298 & 89.5 \\
\hline Yes & 35 & 10.5 \\
\hline
\end{tabular}

Table 3 - Multiple models of the association of quality of life with workaholism in professors of the stricto sensu graduate nursing program ( $N=333)$, Brazil, 2018

\begin{tabular}{|c|c|c|c|c|}
\hline Multiple Models & $\begin{array}{c}p \\
\text { value }\end{array}$ & $\begin{array}{l}\text { Odds ratio } \\
\text { (95\% } \\
\text { confidence } \\
\text { interval) }\end{array}$ & $\begin{array}{c}p \\
\text { value }\end{array}$ & $\begin{array}{c}\text { Odds } \\
\text { ratio } \\
(95 \% \\
\text { confiusted* } \\
\text { interval) }\end{array}$ \\
\hline \multicolumn{5}{|l|}{ Overall quality of life } \\
\hline Excessive work & 0.014 & $\begin{array}{c}0.162 \\
(0.038-0.696)\end{array}$ & 0.024 & $\begin{array}{c}0.183 \\
(0.042-0.803)\end{array}$ \\
\hline Compulsive work & $<0.001$ & $\begin{array}{c}0.314 \\
(0.166-0.594)\end{array}$ & 0.005 & $\begin{array}{c}0.376 \\
(0.190-0.745)\end{array}$ \\
\hline
\end{tabular}

Qualityof life -

Physical domain

Excessive work

Compulsive work

$\begin{array}{cccc}<\mathbf{0 . 0 0 1} & 0.243 & <\mathbf{0 . 0 0 1} & 0.250 \\ & (0.128-0.459) & & (0.125-0.501) \\ <\mathbf{0 . 0 0 1} & 0.247 & 0.001 & 0.255 \\ & (0.119-0.514) & & (0.113-0.576)\end{array}$

Quality of life -

Psychological domain Excessive work

$\begin{array}{lccc}<0.001 & 0.230 & <0.001 & 0.242 \\ & (0.125-0.424) & & (0.126-0.463) \\ <0.001 & 0.152 & <0.001 & 0.153 \\ & (0.058-0.395) & & (0.055-0.427)\end{array}$

Quality of life - Social relationships domain Excessive work

Compulsive work

$\begin{array}{ccc}<0.001 & 0.283 & 0.001 \\ & (0.150-0.536) & \\ 0.003 & 0.385 & 0.018 \\ & (0.204-0.726) & \end{array}$

0.318

$(0.163-0.618)$

0.448

$(0.230-0.874)$

Quality of life environment domain Excessive work

Compulsive work

$\begin{array}{ccc}<0.001 & 0.203 & <0.001 \\ & (0.095-0.431) & \\ <0.001 & 0.288 & 0.002 \\ & (0.153-0.544) & \end{array}$

0.209 (0.093-0.468) 0.351 (0.178-0.689)

Note: *adjusted for gender, age, being physically active, depression, years of teaching in higher education, being a senior professor, weekly hours in addition to workload hours, number of graduate programs linked and students being supervised; Hosmer and Lemeshow of the adjusted models: $p=0.236, p=0.368, p=0.443, p=0.693$ and $p=0.122$, respectively. 
In Table 2, it was observed that $82.3 \%$ of the professors reported low general quality of life. The results also revealed that $19.5 \%$ had a high level of excessive work and $20.1 \%$ of compulsive work.

It was noted that excessive work and compulsive work are negatively and significantly associated with overall, physical, psychological, social relationship and environment domains (Table 3).

\section{DISCUSSION}

The results obtained through the sociodemographic characterization questionnaire showed that most professors are women (87.7\%). In a research carried out with graduate professors at a public institution, $69.4 \%$ of the sample consisted of women ${ }^{(2)}$. The predominance of women in the teaching profession is a phenomenon resulting from historical issues regarding the position of women in society ${ }^{(11)}$. Despite entering the job market, women, in addition to work, accumulate family responsibilities, which contributes to the loss of quality of life.

Another study indicates that the gender variable had a significant difference, with women showing higher rates of Excessive Work ${ }^{(6)}$. It was found that there is a risk profile made up of women, professionals with high workload and overtime, who perceive themselves to be less healthy and have less satisfaction with life in general.

This study showed high QoL in the psychological, social relations and physical domains, however, in the environment domain, it was low. A study carried out with a total of 293 professors from a higher education institution in southern Brazil, using the WHOQOL-BREF, also found a higher score for the psychological, social relations and physical domains ${ }^{(11)}$, with values similar to those found in this study.

In a study carried out with professors from Curitiba, Parana, with the purpose of investigating the QoL of professors from private and public higher education institutions, identified that the highest mean score occurred in the domain of social relations, 71.76 in the Public $\mathrm{HEl}$ and 74.68 in Private $\mathrm{HEl}$, similar to that found in this investigation, that is, the quality of social life was also good ${ }^{(12)}$.

QoL, in all its domains, was negatively correlated with excessive and compulsive work ( $p<0.05)$, which was corroborated by a study carried out in Paraiba that related workaholism with quality of life and it was proved that the greater the addition to work, the lower the quality of life in all its domains: physical, psychological, social relations, environment and overall quality of life ${ }^{(6)}$.
It was possible to observe that the more addicted to work, the greater the deterioration of the professors' $\mathrm{QoL}$, an aspect that indicates that addiction to work can harm the QoL of this professional.

The multiple activities of higher education professors related to stricto sensu graduate studies are carried out in short periods ${ }^{(12)}$, causing them to work excessively. Due to high productivity requirements $^{(14)}$, they can think obsessively about work.

This study shows that workaholism negatively impacts the quality of life of professors due to the strong association of both constructs in those investigated, indicating that by becoming a priority, work deteriorates the quality of life ${ }^{(3)}$, being physical, psychological, social relations and the environment where they live.

\section{Limitations of the study}

As a limitation of this study, the cross-sectional methodology is pointed out, in which the outcome and exposure are measured simultaneously. Also, the self-reported questionnaire, whose answers can be influenced by the participants' interest. For future studies, longitudinal methods with the measurement of objective clinical data are suggested in order to fill the existing gaps regarding the long-term relationship between workaholism and QL.

\section{Contributions to the area of nursing, health or public policy}

The study promoted advances in knowledge about the association of high work demands related to the quality of life of professors. We hope that the results found can provide support for health institutions to be attentive to these addicted professionals, since such behavior does not only compromise sociability with the work team, with the family and their health, but decreases productivity, increases the rates of absenteeism and illness, impacting the quality of services provided.

\section{CONCLUSIONS}

It was noted that the distribution of the domain's overall quality of life, physical, psychological, social relations, and environment, suffered a significant and negative influence from excessive and compulsive work. The high work demands that are characteristic of the stricto sensu professors' work process are directly associated with quality of life.

\section{REFERENCES}

1. Costa AC. As injunções aos docentes na universidade pública: de intelectuais a trabalhadores polivalentes. Rev Trab Educ Saúde. 2016;14:175-95 https://doi.org/10.1590/1981-7746-sol00031

2. Ruza FM, Silva EP. As transformações produtivas na pós-graduação: o prazer no trabalho docente está suspenso? Rev Subj. 2016;16(1):91103. https://doi.org/10.5020/23590777.16.1.91-103

3. Nie Y, Sun H. Why do workaholics experience depression? A study with Chinese University teachers. J Health Psychol. $2016 ; 21(10): 2339-46$. https://doi.org/10.1177/1359105315576350

4. Pinheiro LRS, Carlotto MS. Relações entre a satisfação com a vida e adição ao trabalho. Quad Psicol. 2016;18(2):97-105. https://doi. org/10.5565/rev/qpsicologia.1340

5. Pinheiro LRS, Carlotto MS. Prevalência e preditores da adição ao trabalho em gestores. Rev Psicol. 2018;27(1):1-11. https://doi. org/10.5354/0719-0581.2018.50742 
6. Azevedo FW, Mathias LAST. Adição ao trabalho e qualidade de vida: um estudo com médicos. Einstein. 2017;15(2):130-5. https://doi. org/10.1590/S1679-45082017AO3960

7. United Nations (UN). Transforming our World: The 2030 Agenda for Sustainable Development. [Internet]. 2015 [cited 2019 Dec 01]. Available from: https://sustainabledevelopment.un.org/content/documents/21252030\%20Agenda\%20for\%20Sustainable\%20Development\%20 web.pdf.

8. Ministério da Saúde (BR). Secretaria de Ciência, Tecnologia e Insumos Estratégicos. Departamento de Ciência e Tecnologia. Agenda nacional de prioridades de pesquisa em saúde [Internet]. Brasília: Editora do Ministério da Saúde; 2015. [cited 2019 Dec 02]. 68 p. Available from: http://bvsms.saude.gov.br/bvs/publicacoes/agenda_prioridades_pesquisa_ms.pdf

9. Carlotto MS, Miralles MDL. Tradução, adaptação e exploração de propriedades psicométricas da Escala de Adição ao Trabalho Dutch Work Addiction Scale (DUWAS). Contextos Clín. 2010;3(2):141-50. https://doi.org/10.4013/ctc.2010.32.08

10. Fleck MPA, Louzada S, Xavier M, Chachamovich E, Vieira G, Santos L, et al. Aplicação da versão em português do instrumento abreviado de avaliação da qualidade de vida "WHOQOL-bref". Rev Saúde Públ. 2000;34(2):178-83. https://doi.org/10.1590/S0034-89102000000200012

11. Souto LES, Souza SM, Lima CA, Lacerda MKS, Vieira MA, Costa FM, et al. Fatores associados à qualidade de vida de docentes da área da saúde. Rev Bras Educ Med. 2016;40(3):452-460. https://doi.org/10.1590/1981-52712015v40n3e02362014

12. Caveião C, Sales WB, Visentin A, Hey AP, Escalante MMB, Oliveira ES. Perfil e qualidade de vida de docentes enfermeiros de universidades privadas e pública: estudo com WHOQOL-BREF. Rev APS. 2017;20(2):185-193. https://doi.org/10.34019/1809-8363.2017.v20.15819.

13. Souto BLC, Beck CLC, Trindade LR, Silva RM, Backes DS, Bastos RM. The teaching work in the post-graduation program: pleasure and suffering. Rev Enferm UFSM. 2017;7(1):29-39. https://doi.org/10.5902/2179769222871

14. Frankham J. Employability and higher education: the follies of the 'Productivity Challenge' in the Teaching Excellence Framework. J. Educ. Policy. 2017;32(5):628-641. https://doi.org/10.1080/02680939.2016.1268271 